\title{
FAKTOR-FAKTOR YANG BERHUBUNGAN DENGAN PREEKLAMSIA BERAT PADA IBU HAMIL DI RUMAH SAKIT TK II KARTIKA HUSADA KABUPATEN KUBU RAYA TAHUN 2017
}

\section{Chahyani Erlita ${ }^{1}$, Katarina Iit $^{2}$}

Akademi Kebidanan Panca Bhakti Pontianak

Email korespondensi: akbidpbpontianak@gmail.com

\begin{abstract}
Abstrak
Preeklamsia adalah penyakit dengan tanda-tanda hipertensi, proteinuria, dan edema yang timbul karena kehamilan. Penyakit ini terjadi dalam triwulan ke 3 pada kehamilan, tetapi dapat terjadi sebelumnya misalnya pada mola hidatidosa. Berdasarkan data yang didapatkan di Rumah Sakit Bhayangkara Pontianak bulan maret 2015, didapatkan 7 kasus preeklamsia. Tujuan penelitian ini adalah untuk mengetahui hubungan karakteristik yang meliputi usia, paritas, pendidikan, pekerjaan, status ekonomi dengan kejadian preeklamsia. Penelitian menggunakan metode deskriptif korelasi dengan pendekatan retrospektif. Subyek penelitian ini adalah ibu hamil yang mengalami preeklamsia di Rumah Sakit Bhayangkara Pontianak. Penelitian ini menggunakan sampel seluruh populasi yang ada (total populasi) yaitu sebanyak 39 orang ibu. Hasil penelitian menunjukkan bahwa dari 39 kasus ibu dengan preeklamsia banyak terjadi pada kelompok usia 20-35 tahun (76,92\%), pada ibu hamil primigravida $(82,05 \%)$, tingkat pendidikan Atas $(74,36 \%)$, pada ibu yang tidak bekerja $(56,41 \%)$, ibu dengan status ekonomi kurang $(66,67 \%)$, tidak ada hubungan antara karakteristik ibu hamil dengan kejadian preeklamsia. Bagi tempat pelayanan agar dapat meningkatkan kualitas pelayanan dan memberikan pendidikan kesehatan agar mengurangi kasus preeklamsia.
\end{abstract}

Kata Kunci: Karakteristik, Preeklampsia, Ibu Bersalin

\section{Pendahuluan}

Kehamilan merupakan proses fisiologis yang terjadi dalam tubuh seorang wanita, dimana kehamilan merupakan proses fertilisasi atau menyatunya spermatozoa dan ovum yang dilanjutkan dengan nidasi atau implantasi yang berlangsung selama 40 minggu (Prawirohardjo, 2008). Meskipun kehamilan merupakan proses yang fisiologis tetapi banyak sekali penyulit yang biasanya menyertai dan dapat mengakibatkan tingginya kematian maternal, salah satunya adalah preeklamsia.

Preeklamsia adalah suatu sindroma klinik dalam kehamilan viable (usia kehamilan $>20$ minggu dan/atau janin 500g) yang ditandai dengan hipertensi, proteinuria, dan edema. Gejala ini dapat timbul sebelum kehamilan viable pada penyakit trofoblas (Achadiat,

\footnotetext{
${ }^{1}$ Dosen Akademi Kebidanan Panca Bhakti Pontianak

${ }^{2}$ Dosen Akademi Kebidanan Panca Bhakti Pontianak
}

2010). Sekitar $13 \%$ persalinan terjadi pada wanita berusia antara 15-20 tahun lebih memiliki resiko tinggi baik untuk Ibu maupun untuk janinnya. Selain itu penelitian yang dilakukan oleh Cunningham dan Leveno pada 900 wanita berusia lebih dari 35 tahun memperlihatkan peningkatan bermakna dalam insiden hipertensi, diabetes melitus, solusio plasenta dll.

Angka kematian ibu lebih tinggi pada wanita yang memiliki usia-usia ekstrim yaitu $<20$ dan $>35$ tahun (Cunningham, 2006). Kirakira $85 \%$ preeklamsia terjadi pada kehamilan pertama. Paritas 2-3 meupakan paritas paling aman ditinjau dari kejadian preeklamsia dan resiko meningkat lagi pada grandmultigravida (Bobak, 2005). Preeklamsia merupakan 
penyebab utama mortalitas dan morbiditas ibu dan janin.

Menurut WHO pada tahun 2010 angka kematian ibu didunia 287.000, WHO memperkirakan ada 500.000 kematian ibu melahirkan diseluruh dunia setiap tahunnya, penyumbang terbesar dari angka tersebut merupakan negara berkembang yaitu 99\%. Perempuan meninggal akibat komplikasi selama dan setelah kehamilan dan persalinan. Sebagian besar komplikasi ini berkembang selama kehamilan. Komplikasi utama penyumbang $80 \%$ kematian ibu adalah perdarahan parah (sebagian besar perdarahan postpartum), infeksi (biasanya setelah melahirkan), tekanan darah tinggi selama kehamilan (preeklamsia dan eklamsia) dan aborsi tidak aman (WHO, 2010).

Penelitian-penelitian sebelumnya mengenai preeklamsia yang dilakukan oleh Gitasari tahun 2008 di RSUD dr. M Ashari Pemalang dengan menggunakan responden sebesar 70 ibu hamil yang menderita preeklamsia menunjukkan ada hubungan antara usia ibu dan umur kehamilan dengan kejadian preeklamsia. Penelitian yang dilakukan Lestari tahun 2010 dengan mengambil sampel 38 ibu hamil trimester II dan trimester III dari besar populasi 190 orang di RSUD Kota Semarang menunjukkan ada hubungan antara umur, paritas dan pendidikan dengan pengetahuan ibu hamil tentang preeklamsia dan eklamsia (Latifah, 2014).

Berdasarkan hasil Survey Demografi Kesehatan Indonesia tahun 2012 angka kematian ibu di Indonesia tercatat mengalami kenaikan yang signifikan sekitar 359/100.000 kelahiran hidup. Angka tersebut mengalami kenaikan jika dibandingkan dengan SDKI tahun 2007, dimana angka kematian ibu sekitar 228/100.000 kelahiran hidup. Banyak faktor penyebab kematian ibu diantaranya adalah perdarahan nifas sekitar $26,9 \%$, eklamsi saat bersalin 23\%, infeksi 11\%, komplikasi puerperium $8 \%$. Trauma obstetrik 55, emboli obstetrik 85, aborsi $8 \%$ dan lain-lain 10,9\% (Depkes RI, 2011).

Data profil kesehatan Provinsi Kalimantan Barat menunjukkan pada tahun 2013 di Provinsi Kalimantan Barat, tercatat sebanyak 96 kasus kematian ibu, dengan rincian 3 kasus kematian ibu hamil, 90 kasus kematian ibu pada saat persalinan serta sebanyak 3 kasus kematian ibu nifas. Sehingga jika dihitung angka kematian ibu dengan jumlah kelahiran hidup sebanyak 90.117, maka kematian ibu maternal di Provinsi Kalimantan Barat pada tahun 2013 adalah sebesar 107 per 100.000 kelahiran hidup. Dengan Kota Pontianak memiliki angka kematian ibu berjumlah 7 dari 11.316 kelahiran hidup pada tahun 2013 (Dinkes Kalbar, 2013).

\section{Metode}

Penelitian ini menggunakan jenis penelitian deskriptif korelasional dengan pendekatan cross sectional. Penelitian dilaksanakan pada bulan Februari hingga Juli 2017 di Rumah Sakit TK II Kartika Husada Kabupaten Kubu Raya. Populasi penelitian yaitu seluruh ibu hamil yang mengalami preeklamsia bulan Januari hingga Desember tahun 2016 sebanyak 39 orang. Peneliti menggunakan semua jumlah populasi sebanyak 
39 orang sebagai sampel. Pengumpulan data menggunakan kuesioner kemudian diolah dan dianalisis menggunakan analisis univariate serta analisis bivariate menggunakan uji chi square.

\section{Hasil dan Pembahasan}

Tabel 1. Karakteristik Responden

\begin{tabular}{lcc}
\hline \multicolumn{1}{c}{ Karakteristik } & $\mathrm{n}$ & $\%$ \\
\hline Usia & 9 & 23 \\
$\quad<20->35$ tahun & 30 & 77 \\
$20-35$ tahun & 32 & 82 \\
Paritas & 7 & 18 \\
$\quad 1$ anak & & \\
$\quad>1$ anak & 9 & 23 \\
Pendidikan & 30 & 77 \\
$\quad$ Dasar (SD-SMP) & & 36 \\
$\quad$ Atas (SMA-PT) & 14 & 64 \\
Pekerjaan & 25 & 67 \\
$\quad$ Bekerja & & 33 \\
$\quad$ Tidak Bekerja & 26 & 15 \\
Status Ekonomi & 13 & 85 \\
$\quad$ Kurang (<1.625.000) & & \\
$\quad$ Tinggi (>1.625.000) & 33 & \\
Preeklamsia & 39 & \\
$\quad$ Preeklamsia Ringan & & \\
$\quad$ Preeklamsia Berat & & \\
\hline
\end{tabular}

Berdasarkan tabel 1 didapatkan bahwa sebagian besar dari responden yaitu sebanyak 30 orang $(77 \%)$ berumur $20-35$ tahun, dan sebagian kecil dari responden berumur $<20$ dan $>35$ tahun sebanyak 9 orang (23\%). Berdasarkan tabel 1 didapatkan bahwa sebagian besar dari responden memiliki 1 orang anak yang dilahirkan baik mati maupun hidup yaitu sebanyak 32 orang (82\%) dan sebagian kecil dari responden memiliki > 1 anak yaitu berjumlah 7 (18\%). Berdasarkan tabel 1 didapatkan bahwa sebagian besar dari responden dengan pendidikan Atas (SMA-PT) yaitu sebanyak 30 orang (77\%), sebagiannya lagi dengan pendidikan dasar (SD-SMP) yaitu sebanyak 9 orang (23\%).
Berdasarkan tabel 1 terlihat bahwa sebagian besar dari responden yaitu sebanyak 25 orang $(64 \%)$ tidak bekerja, dan responden yang bekerja sebanyak 14 orang (36\%). Berdasarkan tabel 1 terlihat bahwa sebagian besar dari responden yaitu sebanyak 26 orang (67\%) dengan status ekonomi kurang, dan sebagian kecil responden dengan ekonomi tinggi berjumlah 13 orang (33\%). Berdasarkan tabel 1 terlihat bahwa sebagian besar dari responden yaitu sebanyak 33 orang (85\%) preeklamsia berat, dan sebagian kecil responden dengan preeklamsia ringan berjumlah 6 orang $(15 \%)$. 
Tabel 2. Analisis Bivariat

Kejadian Preeklamsia

\begin{tabular}{|c|c|c|c|c|c|c|c|c|}
\hline \multirow{3}{*}{ Variabel } & \multicolumn{4}{|c|}{ Kejadian Preeklamsia } & \multirow{2}{*}{\multicolumn{2}{|c|}{ Total }} & \multirow{3}{*}{$X^{2}$} & \multirow{3}{*}{ P Value } \\
\hline & \multicolumn{2}{|c|}{ Ringan } & \multicolumn{2}{|c|}{ Berat } & & & & \\
\hline & $\mathrm{N}$ & $\%$ & $\mathrm{~N}$ & $\%$ & $\mathrm{~N}$ & $\%$ & & \\
\hline \multicolumn{9}{|l|}{ Usia } \\
\hline$<20->35$ tahun & 1 & 11,1 & 8 & 88,9 & 9 & 100 & \multirow{2}{*}{3,841} & \multirow{2}{*}{0,1762} \\
\hline 20-35 tahun & 5 & 16,7 & 25 & 83,3 & 30 & 100 & & \\
\hline \multicolumn{9}{|l|}{ Paritas } \\
\hline 1 anak & 5 & 15,6 & 27 & 84,4 & 32 & 100 & \multirow[t]{2}{*}{3,841} & \multirow[t]{2}{*}{0,0129} \\
\hline$>1$ anak & 1 & 14,3 & 6 & 85,7 & 7 & 100 & & \\
\hline \multicolumn{9}{|l|}{ Pendidikan } \\
\hline Dasar (SD-SMP) & 1 & 11,1 & 8 & 88,9 & 9 & 100 & \multirow[t]{2}{*}{3,841} & \multirow[t]{2}{*}{0,1761} \\
\hline Atas (SMA-PT) & 5 & 16,7 & 25 & 83,3 & 30 & 100 & & \\
\hline \multicolumn{9}{|l|}{ Pekerjaan } \\
\hline Bekerja & 2 & 14,3 & 12 & 85,7 & 14 & 100 & \multirow[t]{2}{*}{3,841} & \multirow[t]{2}{*}{0,0337} \\
\hline Tidak Bekerja & 4 & 16,0 & 21 & 84,0 & 25 & 100 & & \\
\hline
\end{tabular}

Berdasarkan hasil penelitian terhadap umur ibu hamil yang mengalami kejadian preeklamsia, diperoleh sebagian besar dari responden berumur 20-35 tahun yaitu sebanyak 30 orang $(76,92 \%)$ dan sebagian kecil dari responden yang berumur <20->35 tahun yaitu sebanyak 9 orang $(23,08 \%)$. Menurut Prawirohardjo (2006), tinggi rendahnya usia seseorang mempengaruhi terjadinya preeklamsia.

Usia sangat mempengaruhi terjadinya preeklamsia, usia yang baik untuk hamil berkisar antara 20-35 tahun. Pada usia tersebut alat reproduksi wanita telah berkembang dan berfungsi secara maksimal. Sebaliknya pada wanita dengan usia dibawah 20 tahun atau diatas 35 tahun kurang baik untuk hamil karena kehamilan pada usia ini memiliki resiko tinggi, seperti terjadinya keguguran atau kegagalan persalinan, bahkan bisa menyebabkan kematian. Wanita yang usianya lebih tua memiliki tingkat resiko komplikasi melahirkan yang lebih tinggi dibandingkan dengan yang lebih muda. Bagi wanita yang berusia diatas 35 tahun, selain fisik mulai melemah juga kemungkinan munculnya berbagai resiko gangguan kesehatan, seperti darah tinggi, diabetes, dan berbagai penyakit lainnya termasuk preeklamsia (Gunawan, 2010).

Berdasarkan penelitian yang dilakukan Ernisfi di Rumah Sakit Bhakti Yudha Depok Tahun 2008 - 2010 menunjukkan dari 100 orang responden yang mengalami preeklamsia terdapat $86 \%$ responden berumur $20-35$ tahun. Berdasarkan hasil penelitian didapatkan sebagian besar dari responden memiliki 1 anak yang dilahirkan baik mati maupun hidup yaitu sebanyak 32 orang $(82,05 \%)$ dan sebagian kecil dari responden memiliki >1 anak yaitu sebanyak 7 orang $(17,95 \%)$.

Paritas merupakan faktor penting yang menunjang keberhasilan kehamilan dan persalinan. Pada primigravida pada pembentukan antibodi meningkatkan (blocking antibodies) atau penghambat pembentukan antibodi, belum sempurna sehingga meningkatkan resiko pada preeklamsia perkembangan preeklamsia semakin 
meningkatkan pada kehamilan pertama. Pada primigravida frekuensi preeklamsia lebih tinggi bila dibandingkan dengan multigravida, terutama primigravida muda. Dengan demikian diharapkan kepada ibu-ibu untuk tidak terlalu dekat jika ingin memiliki anak agar kesejahteraan ibu dan janin terjamin tanpa ada penyulit lain (Prawirohardjo, 2007).

Catatan statistik menunjukkan dari seluruh insiden dunia, dari 5\% - $8 \%$ preeeklamsia dari semua kehamilan, terdapat $12 \%$ lebih dikarenakan oleh primigravida. Berdasarkan hasil penelitian didapatkan bahwa sebagian besar dari responden dengan pendidikan atas (SMA-PT) yaitu sebanyak 29 orang $(74 \%)$, sebagiannya lagi dengan pendidikan dasar (SD-SMP) yaitu sebanyak 10 orang $(26 \%)$.

Tingkat pendidikan seseorang akan berpengaruh dalam memberikan respon terhadap sesuatu yang datang dari luar. Orang yang berpendidikan tinggi akan memberikan respon yang lebih rasional terhadap informasi yang datang dan alasan berfikir sejauh mana keuntungan yang mungkin akan mereka peroleh akan gagasan tersebut. Perempuan yang tidak lagi meyakini atau sudah longgar keyakinannya dengan adat istiadat. Mereka lebih mudah mengadopsi informasi tantang kesehatan dari bidan atau tenaga kesehatan ataupun media cetak atau eletronik (Juariah, 2009).

Dari hasil penelitian Agung Supriandono dan Sulchan Sofoewan menyebutkan bahwa 49,7\% kasus preeklamsia berat mempunyai pendidikan kurang dari 12 tahun. Berdasarkan hasil penelitian didapatkan bahwa sebagian besar dari responden yaitu sebanyak 22 orang
$(56,41 \%)$ tidak bekerja, dan sebagian dari responden yaitu sebanyak 17 orang bekerja (43,59\%). Ibu hamil yang bekerja dan bertanggung jawab untuk pekerjaan rumah tangganya mempunyai resiko komplikasi lima kali lebih besar. Berdasarkan penelitian resiko komplikasi pada ibu hamil meningkat 2-3 kali dengan tingkat stres yang tinggi. Dalam waktu pendek, tingkat stres akan menyebabkan gejala rasa lemas, kurang tidur, perasaan cemas berlebihan, nafsu makan terganggu. Jika tidak diatasi akan dapat menimbulkan masalah kesehatan (Hersianna, 2012).

Berdasarkan hasil penelitian yang dilakukan Sri Karyati, dkk (2014) didapatkan ibu yang tidak bekerja yaitu sebanyak $62,3 \%$ dari 53 responden. Berdasarkan hasil penelitian didapatkan bahwa sebagian besar dari responden dengan status ekonomi kurang yaitu sebanyak 26 orang $(66,67 \%)$, dan sebagian kecil dari responden yaitu sebanyak 13 orang $(33,33 \%)$ dengan status ekonomi tinggi. Sekelompok masyarakat yang kurang mampu untuk membiayai perawatan kesehatan sebagaimana mestinya. Wanita yang memiliki pendapatan rendah dengan pemeriksaan antenatal yang kurang atau tidak sama sekali merupakan faktor predisposisi terjadinya preeklamsia atau eklamsia (Taber, 1994).

Walaupun demikian, menurut Efri Widianti, dkk (2007) penghasilan tak berpengaruh langsung terhadap pengetahuan seseorang. Umur juga sangat mempengaruhi pengetahuan dalam hal pemahaman terhadap informasi yang ada dan semakin bertambah usia seseorang maka pengetahuan juga bertambah dan menjadi matang. 
Hasil penelitian didapatkan dari 9 orang responden yang berumur $<20$ dan $>35$ tahun terdapat 1 orang $(11,1 \%)$ responden mengalami preeklamsia ringan, 8 orang $(88,9 \%)$ mengalami preeklamsia berat, dan dari 30 orang responden yang berumur $20-35$ tahun terdapat 5 orang $(16,7 \%)$ mengalami preeklamsia ringan, 25 orang $(83,3 \%)$ mengalami preeklamsia berat. Dari hasil uji chi square dinyatakan tidak hubungan antara umur ibu yang hamil dengan kejadian preeklamsia. Hal ini ditunjukkan dengan nilai X2 hitung $=0,1762$ lebih kecil dari X2 tabel maka Ho diterima dan Ha ditolak.

Dilihat secara statistik tidak ada hubungan antara usia dengan kejadian preeklamsia, hal tersebut dimungkinkan sebagian besar umur ibu adalah umur reproduksi. Namun menurut Gunawan (2010) Usia sangat mempengaruhi kehamilan, usia yang baik untuk hamil berkisar antara 20-35 tahun. Pada usia tersebut alat reproduksi wanita telah berkembang dan berfungsi secara maksimal. Sebaliknya pada wanita dengan usia dibawah 20 tahun atau diatas 35 tahun kurang baik untuk hamil karena kehamilan pada usia ini memiliki resiko tinggi, seperti terjadinya keguguran atau kegagalan persalinan, bahkan bisa menyebabkan kematian.

Wanita yang usianya lebih tua memiliki tingkat resiko komplikasi melahirkan yang lebih tinggi dibandingkan dengan yang lebih muda. Bagi wanita yang berusia diatas 35 tahun, selain fisik mulai melemah juga kemungkinan munculnya berbagai resiko gangguan kesehatan, seperti darah tinggi, diabetes, dan berbgai penyakit lainnya termasuk preeklamsia. Dari data yang diperoleh peneliti menunjukkan kejadian preeklamsia lebih banyak pada ibu yang berumur 20 - 35 tahun yaitu sebanyak 30 orang $(76,92 \%)$. Secara statistik tidak ada hubungan antara umur ibu dengan kejadian preeklamsia, pernyatan ini sependapat dengan penelitian Dewi Wahyuni (2014) yang menyatakan tidak ada hubungan antara umur dengan kejadian preeklamsia. Hal ini dikarenakan sebagian besar umur ibu berkisar antara 20-35 tahun.

Hasil penelitian didapatkan dari 32 orang responden yang memiliki 1 orang anak terdapat 8 orang $(25 \%)$ responden mengalami preeklamsia ringan,24 orang (75\%) mengalami preeklamsia berat, dan dari 7 orang responden yang memiliki anak 1 terdapat 1 orang $(14,3 \%)$ mengalami preeklamsia ringan, 6 orang $(85,7 \%)$ mengalami preeklamsia berat. Dari hasil uji chi square dinyatakan tidak ada hubungan antara paritas dengan kejadian preeklamsia. Hal ini ditunjukkan dengan nilai $\mathrm{X} 2=0,3535$ lebih kecil dari X2 tabel maka Ho diterima dan Ha ditolak.

Walaupun secara statistik tidak ada hubungan paritas dengan kejadian preeklamsia. Namun data memperlihatkan bahwa kejadian preeklamsia banyak terjadi pada ibu hamil primigravida. Hal ini sependapat dengan Prawirohardjo (2007) yang menyatakan Paritas merupakan faktor penting yang menunjang keberhasilan kehamilan dan persalinan. Pada primigravida pada pembentukan antibodi meningkatkan (blocking antibodies) atau penghambat pembentukan antibodi, belum sempurna sehingga meningkatkan resiko pada preeklamsia perkembangan preeklamsia 
semakin meningkatkan pada kehamilan pertama.

\section{Pada primigravida frekuensi preeklamsia} lebih tinggi bila dibandingkan dengan multigravida, terutama primigravida muda. Dari data yang diperoleh peneliti menunjukkan bahwa pada ibu yang hamil primigravida $(82,05 \%)$ memiliki resiko lebih tinggi dibandingkan yang memiliki > 1 anak. Dari data yang diperoleh peneliti menunjukkan kejadian preeklamsia lebih banyak pada ibu yang memiliki 1 anak yaitu sebanyak 32 orang (82\%). Secara statistik tidak ada hubungan antara umur ibu dengan kejadian preeklamsia, pernyatan ini sependapat dengan penelitian Dewi Wahyuni (2014) yang menyatakan tidak ada hubungan antara paritas dengan kejadian preeklamsia. Hal ini dikarenakan sebagian besar ibu hamil primigravida.

Hasil penelitian didapatkan dari 10 orang responden dengan tingkat pendidikan dasar (SD-SMP) terdapat 1 orang (10\%) responden mengalami preeklamsia ringan,9 orang (90\%) mengalami preeklamsia berat, dan dari 29 orang responden dengan tingkat pendidikan atas (SMA- PT) terdapat 4 orang $(13,79 \%)$ mengalami preeklamsia ringan, 25 orang $(86,21 \%)$ mengalami preeklamsia berat. Dari hasil uji chi square dinyatakan tidak ada hubungan antara pendidikan dengan kejadian preeklamsia. Hal ini ditunjukkan dengan X2 = 0,8549 lebih kecil dari X2 tabel maka Ho diterima dan Ha ditolak.

Walaupun secara statistik tidak ada hubungan antara pendidikan dengan kejadian preeklamsia. Hal tidak sependapat dengan Juariah (2009) tingkat pendidikan seseorang akan berpengaruh dalam memberikan respon terhadap sesuatu yang datang dari luar. Orang yang berpendidikan tinggi akan memberikan respon yang lebih rasional terhadap informasi yang datang dan alasan berfikir sejauh mana keuntungan yang mungkin akan mereka peroleh akan gagasan tersebut. Perempuan yang tidak lagi meyakini atau sudah longgar keyakinannya dengan adat istiadat. Mereka lebih mudah mengadopsi informasi tantang kesehatan dari bidan atau tenaga kesehatan ataupun media cetak atau eletronik (Juariah, 2009).

Dari data yang diperoleh peneliti menunjukkan kejadian preeklamsia lebih banyak pada ibu dengan tingkat pendidikan atas (SMA-PT) yaitu sebanyak 29 orang (74\%). Secara statistik tidak ada hubungan antara pendidikan ibu dengan kejadian preeklamsia, pernyatan ini sependapat dengan penelitian Rozhikan (2007) yang menyatakan tidak ada hubungan antara pendidikan dengan kejadian preeklamsia. Hal dikarenakan sebagian besar ibu berpendidikan SMA atau perguruan tinggi.

Hasil penelitian didapatkan dari 17 orang responden yang bekerja terdapat 2 orang $(11,8 \%)$ responden mengalami preeklamsia ringan, 15 orang $(88,2 \%)$ mengalami preeklamsia berat, dan dari 22 orang responden yang tidak bekerja terdapat 1 orang $(4,5 \%)$ mengalami preeklamsia ringan, 21 orang $(95,5 \%)$ mengalami preeklamsia berat. Dari hasil uji chi square dinyatakan tidak ada hubungan antara pekerjaan dengan kejadian preeklamsia. Hal ini ditunjukkan dengan nilai $\mathrm{X} 2$ hitung $=0,7204$ lebih kecil dari X2 tabel maka Ho diterima dan Ha ditolak. 
Walaupun secara statistik tidak ada hubungan antara pekerjaan dengan kejadian preeklamsia. Namun data memperlihatkan bahwa kejadian preeklamsia banyak yang tidak bekerja. Hal ini tidak sependapat dengan Hersianna (2012) Ibu hamil yang bekerja dan bertanggung jawab untuk pekerjaan rumah tangganya mempunyai resiko komplikasi lima kali lebih besar. Berdasarkan penelitian resiko komplikasi pada ibu hamil meningkat 2-3 kali dengan tingkat stres yang tinggi. Dalam waktu pendek, tingkat stres akan menyebabkan gejala rasa lemas, kurang tidur, perasaan cemas berlebihan, nafsu makan terganggu. Jika tidak diatasi akan dapat menimbulkan masalah kesehatan. Secara statistik hasil uji chi square menyatakan tidak ada hubungan antara pekerjaan dengan kejadian preeklamsia dan hal ini juga tidak sependapat dengan Hersianna (2012).

\section{Kesimpulan}

Berdasarkan hasil penelitian yang telah dilakukan, maka dapat disimpulkan bahwa tidak ada hubungan antara umur, paritas, pendidikan dan pekerjaan ibu hamil dengan kejadian preeklamsia.

\section{Daftar Pustaka}

Achadiat, Chrisdiono M. 2010. Obstetri \& Ginekologi. Jakarta: EGC

Arikunto, S. 2010. Prosedur Penelitian Suatu Pendekatan Praktik. Jakarta: Rineka cipta

BKKBN. 2006. Deteksi Dini Komplikasi Persalinan. Jakarta: BKKBN

Bobak, Lowdermilk. 2005. Keperawatan Maternitas edisi 4. Jakarta: EGC
Cunningham, FG, dkk. 2006. Obstetri Williams Volume I. Jakarta: EGC

.2009. Obstetri Williams Volume II. Jakarta: EGC

Departemen Pendidikan Nasional. 2008. Kamus Besar Bahasa Indonesia. Jakarta: Pusat Bahasa

Depkes RI. 2011. Panduan Pelayanan Antenatal. Jakarta: Depkes RI

Detiana, Prilia. 2013. Hamil Aman dan Nyaman di Atas 30 Tahun. Jakarta: Media Pressindo

Dinkes Kalbar. 2013. Profil Dinas Kesehatan Kalimantan barat. Pontianak: Dinkes Kalbar

Fatmawati, ery dkk. 2011. Asuhan Kebidanan Patologi. Yogyakarta: Pustaka Belajar

Gunawan S. 2010. Reproduksi Kehamilan Dan Persalinan. Jakarta: CV Graha

Hersianna, Nuni. 2012. Hamil Tetap Langsing. Jakarta: Visimedia

Juariah. 2009. Antara Bidan dan Dukun. Jakarta: Majalah Bidan Volume XIII

Kenneth, Leveno. 2009. Obstetri William. Jakarta: EGC

Latifah, 2014. Gambaran Pengetahuan Dan Sikap Ibu Hamil Tentang Preeklamsia. Http://digilib.unimus.ac.id. Diakses: 3 Mei 2015, 20:40 WIB

Madhfoedz. 2006. Metodologi Penelitian. Yogyakarta: Fitramaya

Maskartini. 2015. Upah Minimal Kota Pontianak. Tribun, 2 Maret 2015

Mochtar, Rustam. 1999. Sinobsis Obstetri jilid I. Jakarta: EGC

Notoatmodjo, Soekidjo. 2003. Pendidikan dan Perilaku Kesehatan. Jakarta: Rineka Cipta

2006. Pendidikan dan Perilaku Kesehatan. Jakarta: Rineka Cipta 
Nugroho, Taufan. 2008. Patologi Kebidanan. Jakarta: buku kedokteran

Prawirohardjo, Sarwono. 2006. Ilmu Kebidanan. Jakarta: Yayasan bina pustaka

2008. Ilmu Kebidanan. Jakarta: Yayasan bina pustaka

\section{Rozikhan. 2007. Faktor-faktor Resiko Terjadinya Preeklamsia Berat. Http://eprints.undip.ac.id, diakses: 3 Mei 2015, 20:35 WIB}

Rukiyah, Ai Yeyeh. 2010. Asuhan Kebidanan 4 (Patologi). Jakarta: TIM
Karyati, Sri. 2014. Faktor - Faktor Yang Berkontribusi Pada Kejadian Preeklamsia. Http://ejournal.stikesmuhkudus.ac.id. diakses 1 Juli 2015,04.15 WIB

Sugiyono. 2012. Statistik Untuk Penelitian. Bandung: Alfabeta

Sugono, Dendy. 2008. Kamus Besar Bahasa Indonesia. Jakarta: Pusat Bahasa

Taber, Ben-zion. 1994. Kedaruratan Obstetri Ginekologi, Alih bahasa, Teddy Supriyadi, Johanes Gunawan. Jakarta: EGC

WHO. 2010. Pelayanan Kesehatan Maternal. Jakarta: Media Aesclapius Press 